Ethiopian Journal of Environmental Studies \& Management 10(4): 505 - 519, 2017.

ISSN:1998-0507

doi: https://dx.doi.org/10.4314/ejesm.v10i4.8

Submitted: January 19, 2017

Accepted: May 31, 2017

\title{
ASSESSMENT OF WATER QUALITY OF OBUEYINOMO RIVER, OVIA NORTH EAST LOCAL GOVERNMENT AREA, EDO STATE, SOUTHERN NIGERIA
}

\author{
*ENUNEKU, A., ${ }^{1}$ OKOH, H. ${ }^{2}$ AND ORONSAYE, C. ${ }^{3}$ \\ ${ }^{1}$ Department of Environmental Management and Toxicology, Faculty of Life Sciences, \\ University of Benin, PMB 1154, Benin City, Nigeria. \\ ${ }^{2,3}$ Department of Animal and Environmental Biology, Faculty of Life Sciences, University \\ of Benin, PMB1154, Benin City, Nigeria
}

\begin{abstract}
This study was carried out to assess the water quality of Obueyinomo River using water quality index. Ambient and water temperatures were determined in-situ while total dissolved solids (TDS), total suspended solids (TSS), total solids (TS), turbidity, pH, conductivity, hardness, alkalinity, dissolved Oxygen (DO), Biochemical Oxygen Demand $(B O D)$, chloride, nitrate, phosphate, calcium and magnesium levels were analyzed in the laboratory using standard techniques. With the exception of $D O$, the other physicochemical parameters showed no significant difference $(p>0.05)$ across the stations. Distribution patterns of physicochemical parameters in stations 1, 2 and 3 were analyzed using PCA. There was a strong association for stations 1, 2 and 3 which was also highly associated with nitrates. Hardness, magnesium calcium and phosphate formed a cluster showing the contributions of these ions to water hardness. Alkalinity, suspended solids and chloride formed a cluster suggesting that the suspended solids are largely composed of chlorides. Turbidity, $\mathrm{pH}, \mathrm{BOD}$ and $\mathrm{DO}$ at all the stations exceeded the Federal Ministry of Environment standards for surface water. The water quality index (WQI) values at stations 1, 2 and 3 were 138.45, 122.70 and 170.01 respectively. The parameters responsible for the high values of $W Q I$ as indicated by the water quality rating include turbidity, $\mathrm{pH}$, dissolved oxygen and biochemical oxygen demand. The high WQI values in all the stations studied which exceeded the benchmark of 100 showed that the water from this river is unfit for drinking purposes and should be treated before consumption by inhabitants of the area.
\end{abstract}

Key Words: Physicochemical parameters, River, Water quality index, Contamination

\section{Introduction}

Freshwater from rivers and streams are a necessity for human survival. Sustainable development will be an impossibility without freshwater of adequate quality and quantity.
Approximately one third of Nigerians live with moderate to high water stress (Olorode et al, 2015). Contamination with hazardous chemicals and wastewater and sometimes natural sources is a common phenomenon (Ojekunle, 2000). 
In Nigeria, most rural communities do not have access to safe drinking water (Egboh and Emeshili, 2007). Such rural communities inhabiting the banks of rivers obtain water for domestic purposes from nearby rivers and streams which may be contaminated. This exposes them to water borne diseases and contaminants which are known to pose serious health problems (Odoemelam et al., 2013).

The maintenance of healthy freshwater bodies is dependent on physicochemical properties and biological diversity. Important physical and chemical parameters that affect natural water quality are temperature, $\mathrm{pH}$, turbidity, dissolved oxygen (DO), biochemical oxygen demand (BOD), chemical oxygen demand (COD), alkalinity, Nitrates and Phosphates (Lawson, 2011; Nduka et al., 2008). These parameters are principal factors for the survival of aquatic organisms (Lawson, 2011). Turbid water caused by suspended and colloidal matter such as clay may be the result of soil erosion, urban runoff, algal blooms, and bottom sediment disturbances, silt, organic and inorganic matter, and microscopic organisms (Murhekar, 2011). Alkalinity is commonly used to indicate a system's capacity to buffer against acid impacts. Alkalinity due to the presence of bicarbonate, carbonate and hydroxides of calcium, sodium and potassium (Murhekar, 2011; Lawson, 2011) is vital in neutralizing the acidity of water which increases with dissolved carbon dioxide (Lawson, 2011). Temperature is one of the limiting factors in the aquatic environment (Lawson, 2011). If water temperature is outside the tolerable range for a long time, organisms can be stressed and die. DO is important to health of aquatic ecosystems. All aquatic animals need oxygen to survive.

$\mathrm{pH}$ expresses the acidity or alkalinity of a solution on a logarithmic scale on which 7 is neutral. Lower values are more acid and higher values more alkaline. Most aquatic animals prefer a $\mathrm{pH}$ range of 6.5 - 8.0. Lawson, (2011) reported that aquatic shrimps and crabs require optimum $\mathrm{pH}$ range of 6.8 - 8.7 for maximum growth and reproduction. According to WHO (2011), there is no health-based guideline value for $\mathrm{pH}$, although $6.5-8.5$ is proposed for drinking water.

Nutrient enrichment of surface waters has generated concern due to the ecological impacts on both freshwater and estuarine systems (Prior and Johnes, 2002). Nitrogen and phosphorus species are notable characteristic pollutants for eutrophication of natural waters (Zanin $e t$ al., 1998; Omaka et al., 2007). High concentrations of nitrates in drinking water sources can be fatal to humans and animals (Zatar et al., 1999Monteiro et al., 2003). Elevated concentrations of phosphorus may result in fouling of natural water and production of toxic Cyanobacteria (Omaka, 2007).

Studies of the physicochemical hydrology of water bodies in Nigeria have received a great deal of attention (Asonye et al. (2007); Anyanwu (2012); Ekhator et al. (2012); Akubugwo et al. (2012); Taiwo et al. (2014). Obueyinomo River located in Agemopa community serves as the primary source of water for drinking and various domestic purposes. Thus there is need to ascertain the suitability of the water from the river for domestic purposes.

The aim of this study was to assess the water quality of Obueyinomo River 
using water quality index (WQI). WQI is a very useful and efficient method which can provide a simple characterisation of water quality and it is based on physicochemical parameters such as water temperature, turbidity, TSS, TDS, $\mathrm{pH}$, DO, BOD, nitrate, chloride, phosphate and calcium.

\section{Materials and Methods}

Obueyinomo River in Agemopa community is located in Ovia North East local government area of Edo state (figure 1). The river is located located between latitude $\mathrm{N} 06^{\circ} 37^{\prime} 467^{\prime \prime}$, longitude $005^{\circ} 34^{\prime} 49.1^{\prime \prime} \mathrm{E}$ and latitude N06 $37^{\circ} 26.8^{\prime \prime}$, longitude $005^{\circ} 34^{\prime} 31^{\prime \prime}$. The climate around the river area consists of two seasons, the rainy season which starts from May to October and the dry season which starts from November to April. The region is a rainforest biome. The river is the primary source of water for drinking and other domestic activities by the villagers. The primary human activity in this community is farming.

Sampling was carried out monthly from February to June, 2016. The samples were collected from three stations (Stations 1, 2 and 3) designated along the course of the river and these stations were at least 100 meters apart (Figure 1). Selection of the station was based on accessibility. Water samples were collected between the hours of 700 to $1000 \mathrm{GMT}$.

\section{Sampling Stations}

Station 1 was located upstream of other stations and shaded by mesh of grasses and shrubs. This is located between latitude $\mathrm{N} 06^{\circ} 37^{\prime} 467^{\prime \prime}$ and longitude $005^{\circ} 34^{\prime} 49.1^{\prime \prime} \quad$ E. The substratum is sandy mixed with decaying organic matter. The water is cloudy and partly covered by some floating and emergent plants. Dominant plants at this station include Elaeis guineensis, Smilax anceps and Dryopteris filixmax. No activity human was observed at this station.

Station 2 was located between latitude $\mathrm{N} 06^{\circ 0} 37^{\prime} 29.6^{\prime \prime}$ and longitude $005^{\circ} 34^{\prime} 30.6^{\prime \prime} \mathrm{E}$. The plants that were observed in this station were Setaria babarta, Elaeis guineensis, Heavea brazilensis, Xanthosoma sagetefolius and Palisota hirsuta.

Station 3 was located between

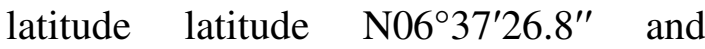
longitude $005^{\circ} 34^{\prime} 31^{\prime \prime} \mathrm{E}$. The substratum is composed of fine sand and partly covered with fallen leaves and logs of wood. It is fast flowing and water is clear. Vegetation around this station includes Elaeis guineensis, Palisota hirsuta, Nymphea lotus. Human activities observed at this station include processing food agricultural products, washing of cloths, bikes and dishes. 


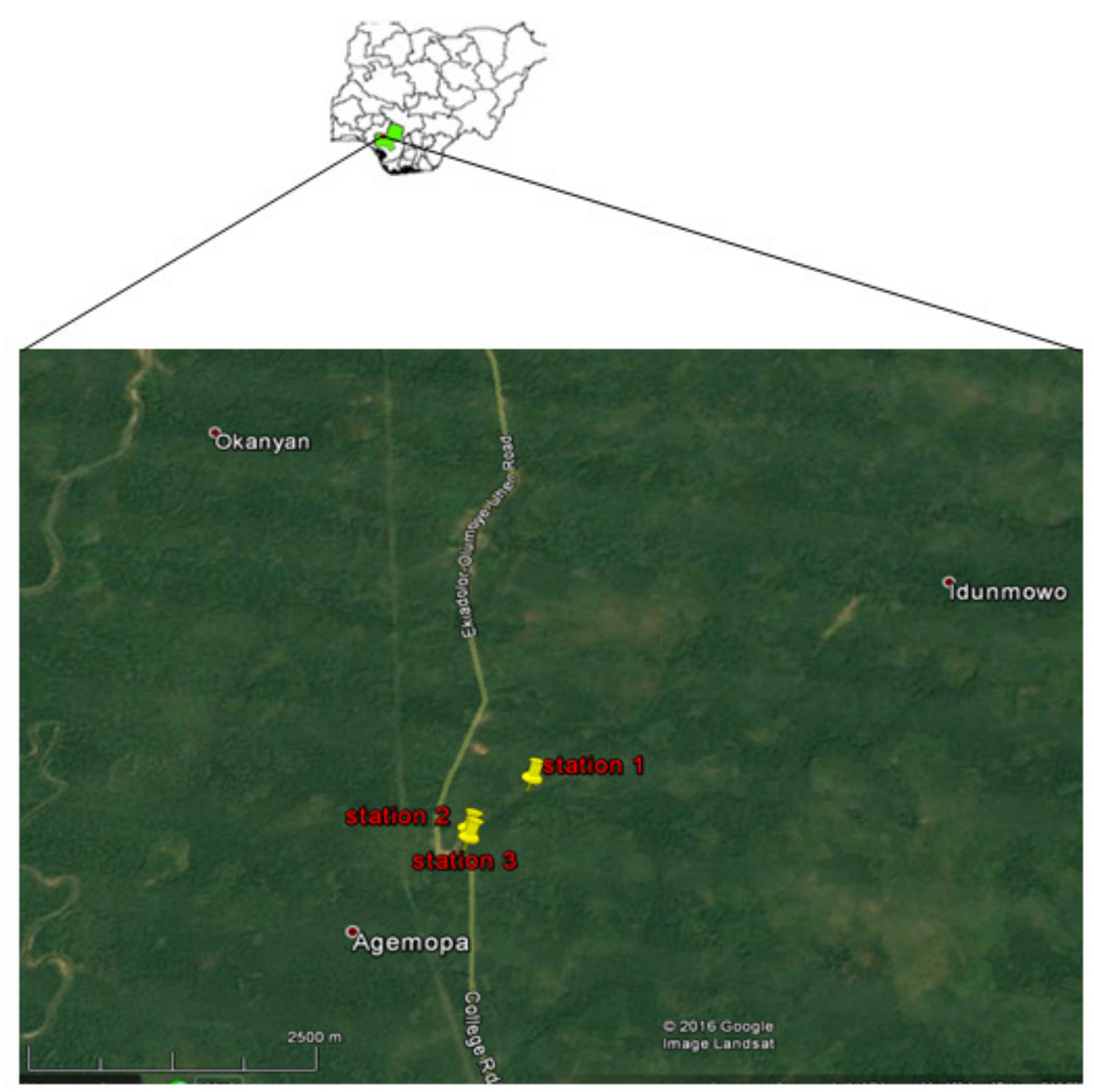

Figure 1; Map showing sampling stations 1, 2 and 3 (yellow pins) at Obueyinomo River

Water Sample Collection and Periodicity

The sampling stations where visited each month from January 2016 to April 2016. Water samples for the determination of physical, chemical and biological studies were collected between 9 am and 12 noon each sampling day. Water and air temperature were determined in situ using $0-100^{\circ} \mathrm{C}$ mercury in glass thermometer. Water samples for DO and BOD determination were collected using $250 \mathrm{ml}$ reagent bottles with glass stoppers. For DO, the oxygen content of the water was immediately fixed by adding $1.5 \mathrm{ml}$ each of Winkler's solutions A (Manganous sulphate) and B (Potassium hydroxide in Potassium iodide). The water samples for BOD were immediately wrapped in black polythylene bags and transported to the laboratory. Surface water samples for the determination of $\mathrm{pH}$, conductivity, COD, alkalinity, hardness, solids and major ions were collected by immersing a 1 
liter plastic bottle $50 \mathrm{~cm}$ below the water surface and allowing it to fill before removing it from the water and were stored at $4^{\circ} \mathrm{C}$ and taken to the laboratory for analysis.

\section{Determination of Physical and Chemical Characteristics}

$\mathrm{pH}$ of the water sample was determined using the Griffin battery operated $\mathrm{pH}$ meter (Hi-1992). The conductivity of the water was measured using a HACH conductivity (Hanna 911) meter by dipping the probe into the sample. Total Solids, Total Dissolved Solids and Total Suspended solids were determined gravimetrically as described in APHA, 1998. The turbidity of water (Nephelometric Turbidity Unit, NTU) was determined using the turbidity meter (Spectronic 2ID spectrophotometer) at room temperature. The dissolved oxygen and biochemical oxygen demand was determined using the Winkler's method APHA, (1998). Total alkalinity of the water was determined by the titrimetric method described by APHA (1998). Chloride ion concentration was determined following by APHA (1998) and expressed in $\mathrm{mg} / \mathrm{L}$. Nitrate was determined by the colorimetric methods using phenoldisulphonic acid as described in APHA, (1998) using the Milton Roy Spectronic 21D Spectrophotometer. Ascorbic acid method (APHA, 1998) was used to determine phosphate concentration using the Milton Roy Spectronic 21D Spectrophotometer to read the absorbance. Calcium and Magnesium were determined titrimetrically following APHA, 1998).

\section{Statistical Analysis}

Statistical analysis for central tendency and dispersion were carried out using SPSS 16.0 windows. Inter-station comparisons were carried out to test for significant differences in the physiochemical conditions and the faunal diversity using parametric analysis of variance (ANOVA). Duncan multiple range (DMR) tests were further performed to determine the location of significant differences. Correlation analysis was used to determine the relationship between the physicochemical parameters. Principal component analysis (PCA) was done to determine the distribution patterns of physicochemical parameters in the studied stations. PCA was done using JMP statistical software v. 10 (SAS Institute). The principal components were extracted with eigenvalues $>1$ through varimax rotation. Water Quality Index (WQI)

Water Quality Index (WQI) is a very useful and efficient method which can provide a simple characterisation of water quality and it is based on some very important parameters such as temperature, turbidity, TSS, TDS, $\mathrm{pH}$, DO, BOD, nitrate, chloride, phosphate and calcium. In this study, Water Quality Index (WQI) was calculated by using the Weighted Arithmetic Index method as described by (Cude, 2001). In this model, different water quality components are multiplied by weighting factor and are then aggregated using simple arithmetic mean.

In assessing the quality of water in this study, firstly, the quality rating scale (Qi) for each parameter was calculated by using the following equation;

$\mathrm{Qi}=\{[(\mathrm{V}$ actual $-\mathrm{V}$ ideal $) /(\mathrm{V}$ standard $-\mathrm{V}$ ideal $)$ * 100$\}$

Where;

Qi = Quality rating of ith parameter for a total of $n$ water quality parameters 
$\mathrm{V}$ actual $=$ Actual value of the water quality parameter obtained from laboratory analysis

$\mathrm{V}$ ideal = Ideal value of that water quality parameter can be obtained from the standard Tables.

$\mathrm{V}$ ideal for $\mathrm{pH}=7$ and for other parameters it is equalling to zero, but for DO V ideal $=14.6 \mathrm{mg} / \mathrm{L}$

$\mathrm{V}$ standard $=$ Recommended Federal Ministry of Environment permissible limits standard of the water quality parameter.

Then, after calculating the quality rating scale (Qi), the Relative (unit) weight (Wi) was calculated by a value inversely proportional to the recommended standard $(\mathrm{Si})$ for the corresponding parameter using the following expression;

$\mathrm{Wi}=1 / \mathrm{Si}$
Where,

$\mathrm{Wi}=$ Relative (unit) weight for $\mathrm{nth}$ parameter

$\mathrm{Si}=$ Standard permissible value for nth parameter

$1=$ Proportionality constant.

Finally, the overall WQI was calculated by aggregating the quality rating with the unit weight linearly by using the following equation:

$\mathrm{WQI}=\Sigma \mathrm{WiQi} / \Sigma \mathrm{Wi}$

Where,

Qi $=$ Quality rating

$\mathrm{Wi}=$ Relative weight

In general, WQI is defined for a specific and intended use of water. In this study the WQI was considered for human consumption and the maximum permissible WQI for the drinking water was taken as 100 score (Table 1).

Table 1: Grades Water Quality Index and status of water quality

\begin{tabular}{ll}
\hline Water Quality Index Levels & Description \\
\hline$<50$ & Excellent \\
$50-100$ & Good \\
$100-200$ & Poor \\
$200-300$ & Very poor (bad) water \\
$>300$ & Unsuitable (unfit)for drinking \\
\hline
\end{tabular}

\section{Results and Discussion}

Physicochemical Parameters

The summary of the physical and chemical parameters of the study stations along a stretch of Obueyinomo River are presented in table 2. The table shows the mean, standard deviation, minimum and maximum values for each parameter analysed for the different stations. 
Table 2: Summary of the physical and chemical characteristics of water at the designated stations along a stretch of Obueyinomo River

\begin{tabular}{|c|c|c|c|c|c|}
\hline Parameter & $\begin{array}{l}\text { Station } 1 \\
\overline{\mathrm{x}} \pm \text { SD }\end{array}$ & $\begin{array}{l}\text { Station } 2 \\
\overline{\mathrm{x}} \pm \text { SD }\end{array}$ & $\begin{array}{l}\text { Station } 3 \\
\bar{x} \pm S D\end{array}$ & p-Value & NIS \\
\hline Water Temp. $\left({ }^{\circ} \mathrm{C}\right)$ & $\begin{array}{l}26.18 \pm 0.93 \\
(25.00-27.00)\end{array}$ & $\begin{array}{l}26.04 \pm 0.94 \\
(25.00-27.30)\end{array}$ & $\begin{array}{l}25.38 \pm 0.84 \\
(24.80-26.80)\end{array}$ & $\mathrm{p}>0.05$ & 35.00 \\
\hline TDS & $\begin{array}{l}19.43 \pm 16.67 \\
(5.30-42.40)\end{array}$ & $\begin{array}{l}9.89 \pm 6.68 \\
(5.30-21.20)\end{array}$ & $\begin{array}{l}7.42 \pm 2.90 \\
(5.30-10.60)\end{array}$ & $\mathrm{p}>0.05$ & 500.00 \\
\hline TSS & $\begin{array}{l}4.93 \pm 2.84 \\
(0.67-8.00)\end{array}$ & $\begin{array}{l}5.40 \pm 3.77 \\
(2.33-11.67)\end{array}$ & $\begin{array}{l}9.73 \pm 3.21 \\
(7.00-15.00)\end{array}$ & $\mathrm{p}>0.05$ & $<10.00$ \\
\hline $\mathrm{TS}$ & $\begin{array}{l}23.70 \pm 15.04 \\
(11.73-46.07)\end{array}$ & $\begin{array}{l}15.29 \pm 10.40 \\
(7.63-32.87)\end{array}$ & $\begin{array}{l}17.15 \pm 5.04 \\
(12.63-25.60)\end{array}$ & $\mathrm{p}>0.05$ & \\
\hline Turbidity & $\begin{array}{l}8.67 \pm 5.65 \\
(0.33-15.33)\end{array}$ & $\begin{array}{l}12.07 \pm 9.41 \\
(2.00-27.00)\end{array}$ & $\begin{array}{l}16.33 \pm 6.06 \\
(9.00-25.33)\end{array}$ & $\mathrm{p}>0.05$ & 5.00 \\
\hline $\mathrm{pH}$ & $\begin{array}{l}6.31 \pm 0.45 \\
(5.60-6.73)\end{array}$ & $\begin{array}{l}6.12 \pm 0.60 \\
(5.17-6.73)\end{array}$ & $\begin{array}{l}6.21 \pm 0.40 \\
(5.73-6.67)\end{array}$ & $\mathrm{p}>0.05$ & $6.50-8.50$ \\
\hline Conductivity & $\begin{array}{l}36.67 \pm 31.45 \\
(10.00-80.00)\end{array}$ & $\begin{array}{l}18.67 \pm 12.61 \\
(10.00-40.00)\end{array}$ & $\begin{array}{l}14.00 \pm 5.48 \\
(10.00-20.00)\end{array}$ & $\mathrm{p}>0.05$ & \\
\hline Hardness & $\begin{array}{l}9.33 \pm 3.13 \\
(6.00-14.00)\end{array}$ & $\begin{array}{l}11.33 \pm 4.88 \\
(6.00-19.33)\end{array}$ & $\begin{array}{l}10.27 \pm 2.39 \\
(6.67-13.33)\end{array}$ & $\mathrm{p}>0.05$ & \\
\hline Alkalinity & $\begin{array}{l}9.87 \pm 2.38 \\
(6.67-12.00)\end{array}$ & $\begin{array}{l}11.60 \pm 3.00 \\
(8.00-15.33)\end{array}$ & $\begin{array}{l}16.13 \pm 12.80 \\
(6.67-38.67)\end{array}$ & $\mathrm{p}>0.05$ & \\
\hline DO & $\begin{array}{l}4.27^{\mathrm{a}} \pm 0.88 \\
(3.37-5.43)\end{array}$ & $\begin{array}{l}2.82^{\mathrm{b}} \pm 1.25 \\
(1.90-4.83)\end{array}$ & $\begin{array}{l}2.04^{\mathrm{b}} \pm 0.93 \\
(1.23-3.47)\end{array}$ & $\mathrm{P}<0.05$ & 7.50 \\
\hline BOD & $\begin{array}{l}1.76 \pm 0.73 \\
(0.57-2.53)\end{array}$ & $\begin{array}{l}1.23 \pm 0.63 \\
(0.77-2.30)\end{array}$ & $\begin{array}{l}1.93 \pm 0.99 \\
(0.87-3.23)\end{array}$ & $\mathrm{p}>0.05$ & \\
\hline Chloride & $\begin{array}{l}13.17 \pm 2.12 \\
(11.72-16.50)\end{array}$ & $\begin{array}{l}14.11 \pm 1.66 \\
(11.78-16.47)\end{array}$ & $\begin{array}{l}14.58 \pm 3.87 \\
(11.77-21.18)\end{array}$ & $\mathrm{p}>0.05$ & \\
\hline Nitrate & $\begin{array}{l}1.44 \pm 1.47 \\
(0.16-3.80)\end{array}$ & $\begin{array}{l}1.01 \pm 0.68 \\
(0.29-1.90)\end{array}$ & $\begin{array}{l}0.96 \pm 0.64 \\
(0.36-1.63)\end{array}$ & $\mathrm{p}>0.05$ & 200.00 \\
\hline Phosphate & $\begin{array}{l}0.48 \pm 0.66 \\
(0.06-1.64)\end{array}$ & $\begin{array}{l}0.56 \pm 0.85 \\
(0.05-2.08)\end{array}$ & $\begin{array}{l}0.50 \pm 0.69 \\
(0.04-1.73)\end{array}$ & $\mathrm{p}>0.05$ & \\
\hline Calcium & $\begin{array}{l}1.81 \pm 0.40 \\
(1.33-2.40)\end{array}$ & $\begin{array}{l}2.03 \pm 0.82 \\
(1.07-3.21)\end{array}$ & $\begin{array}{l}1.92 \pm 0.44 \\
(1.33-2.40)\end{array}$ & $\mathrm{p}>0.05$ & 5.00 \\
\hline Magnesium & $\begin{array}{l}1.17 \pm 0.60 \\
(0.49-1.95)\end{array}$ & $\begin{array}{l}1.52 \pm 0.84 \\
(0.49-2.76)\end{array}$ & $\begin{array}{l}1.33 \pm 0.58 \\
(0.49-1.94)\end{array}$ & $\mathrm{p}>0.05$ & \\
\hline
\end{tabular}

All units are in $\mathrm{mg} / \mathrm{L}$ except otherwise mentioned p $>0.05$ - No Significant Difference; $p<0.05$ - Significant Difference

Similar Superscripts in a row - No Significant Difference

NIS: Nigerian Industrial Standards

Mean ambient temperatures were $30.14 \pm 1.28, \quad 29.80 \pm 1.19 \quad$ and $29.46 \pm 1.73^{\circ} \mathrm{C}$ in stations 1,2 and 3 respectively. Mean water temperatures were $26.18 \pm 0.93, \quad 26.04 \pm 0.94$ and $25.38 \pm 0.84^{\circ} \mathrm{C}$ in stations 1,2 and 3 respectively. From the study, the temperature of the water across the stations were within the stipulated limit of $35^{\circ} \mathrm{C}$ by Federal Ministry of Environment (FMEnv). Similar values of water temperature were obtained by 
Ekhaise and Anyasi (2005) at unperturbed portion of Ikpoba River. The water temperature values obtained in this study were slightly lower than what was obtained by Dimowo (2013) in the assessment of physico-chemical parameters of River Ogun. The mean values of total dissolved solids were 19.43, 9.89 and 7.42 in stations 1,2 and 3 respectively. The mean values for total suspended solids were $4.93 \mathrm{mg} / \mathrm{L}, 5.40$ $\mathrm{mg} / \mathrm{L}$ and $9.73 \mathrm{mg} / \mathrm{L}$ in stations 1,2 and 3 respectively. The mean values for total solids were $23.70 \pm 15.04,15.29 \pm 10.40$ and $\mathrm{mg} / \mathrm{l}$ at stations 1,2 and 3 respectively. The mean levels of total dissolved solids and suspended solids across the stations in this study were in consonance the stipulated values by FMENv standards for surface water. TDS concentrations in this water body exhibited significant and positive correlations with the conductivity and phosphate concentrations in the water. These relationships indicate that dissolved solids in this water body was mainly constituted by ions. The levels of total dissolved and suspended solids recorded in this study were lower when compared to the range of $64.21-320.06$ $\mathrm{mg} / \mathrm{L}$ and 11.29 - $36.01 \mathrm{mg} / \mathrm{L}$ respectively as documented by Duru and Nwanekwu (2012) in their study of physicochemical and microbial status of Nworie River, Owerri, Imo State, Nigeria. The variations can be attributed to spatial and temporal differences.

Mean values for turbidity were $8.67 \pm 5.65,12.07 \pm 9.41$ and $16.33 \pm 6.06$ NTU in stations 1, 2 and 3 respectively. The turbidity levels across all the stations did not comply favourably with FMENv. stipulated value of 5.00 NTU for surface water. These relatively high levels of turbidity could be attributed to the presence of decaying organic matter. The turbidity levels obtained in this study were lower than the range of 21.00 to 29.40 NTU obtained by Rim-Rukeh et al. (2006) on the effects of Agricultural Activities on the Water Quality of Orogodo River, Agbor Nigeria. Mean values for $\mathrm{pH}$ were $6.31 \pm 0.45,6.12 \pm 0.60$ and $6.21 \pm 0.40$ respectively. The slightly acidic condition of Obueyinomo River is typical of the tropical aquatic bodies. Reference had earlier been made on this condition by Ogbeibu and Anagboso (2003) in their study of physicochemical characteristics of Uto River. At average, the $\mathrm{pH}$ values across the stations did not comply with FMENv. stipulated values of $6.50-8.50$ for surface water. According to Rim-Rukehet al. (2006) acidic conditions in an aquatic body is attributable to humic acid formed from decaying organic matter. $\mathrm{pH}$ exhibited a positive and significant correlation with the nitrate concentration. This may have resulted from the fact that the dissolution nitrogenous compounds in the water associates strongly with water $\mathrm{pH}$. For electrical conductivity, the highest value $(80.00 \mu \mathrm{S} / \mathrm{cm})$ was recorded in station 1 while the lowest value $(10.00 \mu \mathrm{S} / \mathrm{cm})$ was recorded at all stations in different time intervals. The mean values for electrical conductivity were $36.67 \pm 31.45$, $18.67 \pm 12.61$ and $14.00 \pm 5.48 \mu \mathrm{S} / \mathrm{cm}$ in stations 1, 2 and 3 respectively. Conductivity is a function of ions in water sample (Chinedu et al., 2011). The conductivity values obtained in this study were low when compared to the range of $102.90-513.08 \mu \mathrm{S} / \mathrm{cm}$ obtained by Duru and Nwanekwu (2012) in their study of physicochemical and microbial status of 
Nworie River, Owerri, Imo State, Nigeria.

Mean values for hardness were $9.33 \pm 3.13,11.33 \pm 4.88$ and $10.27 \pm 2.39$ $\mathrm{mg} / \mathrm{l}$ in stations 1,2 and 3 respectively. Chemically, hardness is often defined as the sum of polyvalent cation concentrations dissolved in water (Wilson, 2010). In fresh waters, the principal hardness-causing ions are Calcium and Magnesium. Strontium, Iron, Barium and Manganese ions also contribute (USEPA, 1976). The levels of hardness across the stations were not significantly different from one another. Mean values for alkalinity across the stations were $9.87 \pm 2.38,11.60 \pm 3.00$ and $16.13 \pm 12.80 \mathrm{mg} / \mathrm{l}$ in stations 1,2 and 3 . The alkalinity values obtained in this study were relatively low when compared to the range of $20.00-32.00 \mathrm{mg} / \mathrm{L}$ obtained by Ahiarakwem and Onyekuru (2011) in their comparative assessment of the physico-chemical and microbial trends in Njaba River, Southeastern Nigeria. The difference can be attributed to variations that may have resulted from alkalinity constituent as stated above

The mean values of DO were 4.27 $\mathrm{mg} / \mathrm{L}, \quad 2.82 \mathrm{mg} / \mathrm{L}$ and $2.04 \mathrm{mg} / \mathrm{L}$ in stations 1,2 and 3 respectively. The values for dissolved oxygen across the stations showed significant difference $(\mathrm{p}<$ 0.05 ) and Duncan multiple range test indicated that this arose from station 1 . DO is the oxygen present in a dissolved form in a water body (DWAF, 1993). It is one of the predictors of the ability of a water body to hold aquatic life forms (APHA, 2005). Dissolved oxygen levels of Obueyinomo River were less than the stipulated value of $7.50 \mathrm{mg} / \mathrm{L}$ by FMEnv for surface water. Values similar to what was recorded in this study were documented by Olorode et al. (2015) in Imo River. The highest mean value of BOD $(1.93 \mathrm{mg} / \mathrm{L})$ was obtained in station 3 while the lowest value $(1.23 \mathrm{mg} / \mathrm{L})$ was obtained in station 2. Mean values for BOD were $1.76 \pm 0.73,1.23 \pm 0.63$ and $1.93 \pm 0.99$ in stations 1,2 and 3 . The values of $\mathrm{BOD}$ at the three stations showed no significant difference $(p>0.05)$. Other indirect laboratory test for assessing the DO is the BOD which is the amount of oxygen required to biologically break down a contaminant (Ugwu and Wakawa, 2012). BOD therefore is an important parameter of water indicating the health scenario of freshwater bodies (Bhatti and Latif, 2011). The BOD values obtained in this study were low when compared to the range of $9.55-13.21 \mathrm{mg} / \mathrm{L}$ obtained by Ugwu and Wakawa (2012). The highest value $(21.18 \mathrm{mg} / \mathrm{L})$ for chloride was recorded in station 3 while the lowest value $(11.72 \mathrm{mg} / \mathrm{L})$ was recorded in station 1 . The mean values for chloride were $13.17 \pm 2.12, \quad 14.11 \pm 1.66$ and $14.58 \pm 3.87 \mathrm{mg} / \mathrm{l}$ in stations 1,2 and 3 respectively. The highest mean value of nitrate $(1.44 \mathrm{mg} / \mathrm{L})$ was recorded at station 1 and the lowest $(0.96 \mathrm{mg} / \mathrm{L})$ at station 3. The nitrate concentrations in the water were $1.44 \pm 1.47,1.01 \pm 0.68$ and $0.96 \pm 0.64 \mathrm{mg} / 1$ in stations 1,2 and 3 respectively. Mean values for phosphates were $0.48 \pm 0.66,0.56 \pm 0.85$ and $0.50 \pm 0.69$ $\mathrm{mg} / \mathrm{l}$ in stations 1,2 and 3 respectively.

Results from this study showed that chloride was dominant to other anions (nitrate and phosphate). Duru and Nwanekwu (2012) documented similar variation in Nworie River. This is contrary to the observation made by Ugwu and Wakawa (2012) in which nitrate was recorded as the most 
dominant anion. This variation is attributable to anthropogenic activities on-going at the watershed as nitrate levels over $10 \mathrm{mg} / \mathrm{L}$ in natural waters normally indicate man made pollution (Ugwu and Wakawa, 2012). Nitrate and phosphate concentrations exhibited inverse and positive significant correlations with magnesium. Thus nitrate displaces magnesium and vice versa. The positive correlation between phosphate and magnesium is an indication that both probably are from the same source as evidenced in the PCA analysis where they formed a cluster. The highest mean value of calcium (2.03 $\mathrm{mg} / \mathrm{L})$ was recorded at station 2 and the lowest $(1.81 \mathrm{mg} / \mathrm{L})$ was at station 1 . Mean values for calcium were $1.81 \pm 0.40$, $2.03 \pm 0.82$ and $1.92 \pm 0.44 \mathrm{mg} / \mathrm{l}$ in stations 1, 2 and 3 respectively. Calcium recorded higher concentration than magnesium. A similar trend was documented by Aguet al. (2014) in Obinna River. This order is consistent with the common trend observed in Nigerian inland freshwaters in which calcium and magnesium are the most important cations. The concentration of calcium across the stations were low when compared to the range of $9.26-19.24 \mathrm{mg} / \mathrm{L}$ obtained by Anyanwu (2012) in his study of physicochemical and some trace metal analysis of Ogba River, Benin City, Nigeria. Calcium levels of Obueyinomo River compared favourably with the stipulated value of $5.00 \mathrm{mg} / \mathrm{L}$ by FMEnv for surface water. Mean values for magnesium were $1.17 \pm 0.60,1.52 \pm 0.84$ and $1.33 \pm 0.58 \mathrm{mg} / 1$ in stations 1, 2 and 3 respectively. Across stations, mean values for ambient temperature, water temperature, total dissolved solids, total suspended solids, total solids, turbidity, electrical conductivity, hardness, BOD, Chloride, Phosphate, Calcium and magnesium showed no significant difference ( $\mathrm{p}>0.05)$.

Test of Relationship amongst the Physicochemical Parameters

Correlation statistics was adopted in testing the relationship between the physicochemical parameters and the result is shown in table 3. An inverse and significant relationship was observed between water temperature and $\mathrm{pH}$ ( $\mathrm{r}=-$ 0.679). The TDS levels in the water exhibited a positive and significant relationship with conductivity $(\mathrm{r}=1.0000)$ and phosphate $(\mathrm{r}=0.552)$ while TSS exhibited the same pattern of relationships with turbidity $(\mathrm{r}=0.785)$ and phosphate $(\mathrm{r}=0.618)$. TS showed positive and significant relationships with conductivity $\quad(r=0.938), \quad$ hardness $(\mathrm{r}=0.613)$, phosphate $(\mathrm{r}=0.748)$, calcium $(\mathrm{r}=0.539)$ and magnesium $(\mathrm{r}=0.522)$ concentrations in the water. An inverse relationship was observed between hardness and nitrate while the former showed positive correlation with phosphate, calcium and magnesium.

\section{Distribution Patterns of Physicochemical Parameters in the Study Areas}

Figure 2 shows distribution patterns of physicochemical parameters in stations 1,2 and 3 was analysed using principal component analysis (PCA). Component 1 made up $36.4 \%$ of the PCA while component 2 made up $21.7 \%$. There was a strong association between stations 1,2 and 3 (clustered on one side) which was also highly associated with nitrates. Hardness, magnesium calcium and phosphate formed a cluster showing the contributions of these ions to water hardness. Alkalinity, suspended solids 
and chloride formed a cluster suggesting that the suspended solids are largely composed of chlorides. Conductivity and

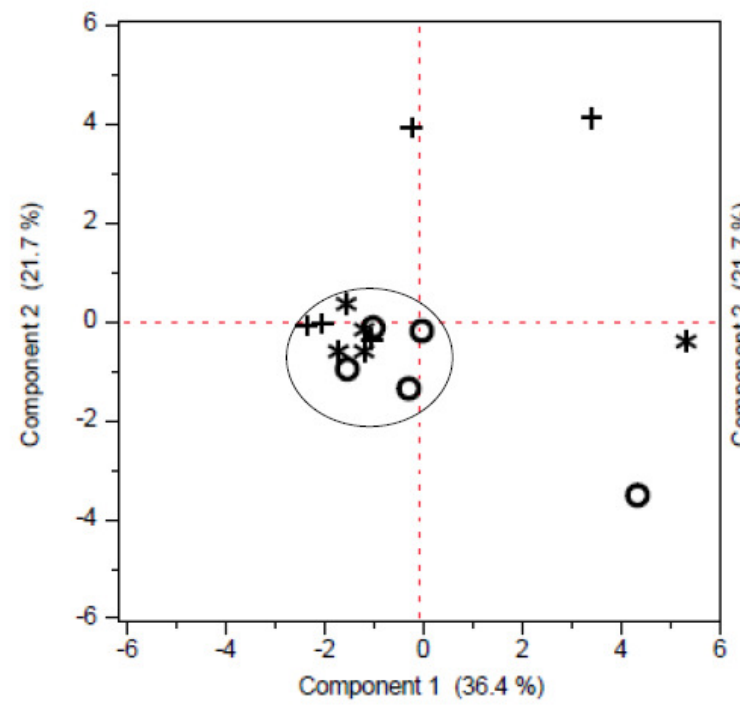

total dissolved solids clustered on one side showing a relationship between conductivity and total dissolved solids.

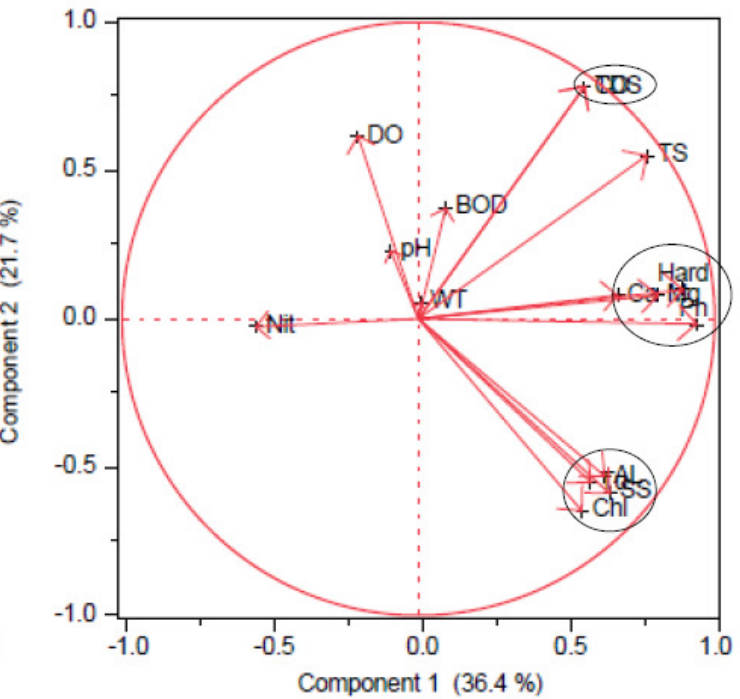

Figure 2: Distribution patterns of physicochemical parameters in stations 1,2 and 3 characterised by PCA: +station 1; *station 2; o station 3. DO: Dissolved oxygen; BOD: Biochemical Oxygen Demand; Hard: Hardness; Mg: Magnesium; Ca: Calcium, Ph: Phosphorus; AL: Aluminium; SS: Suspended solids; Chl: Chloride; AT: Air Temperature; WT: Water Temperature; Nit: Nitrates

Assessment of the Water Quality (WQI)

The water quality of Obueyinomo River was assessed using water quality index. Table 3 shows the summary of the water quality across the stations. Figure 3 shows the contribution of the various parameters to the overall variation in the WQI values across the stations.

Table 3: Summary of the Water Quality Index across the Stations

\begin{tabular}{lllll} 
& Station 1 & Station 2 & Station 3 & Benchmark \\
\hline WQI & 138.45 & 122.70 & 170.01 & 100.00 \\
\hline
\end{tabular}




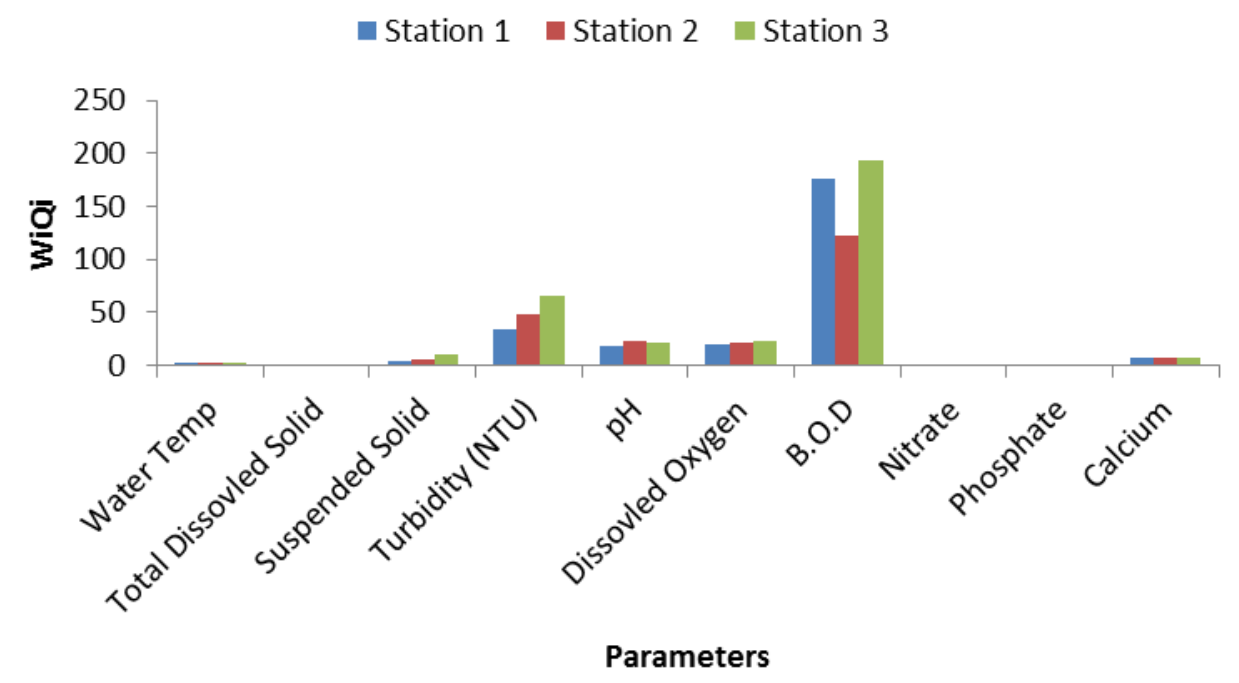

Fig. 3: Spatial Variations in the Quality Rating

Water quality index (WQI) in was adopted in the assessing the water quality and health status of Obueyinomo River. Water quality index (WQI) is a means to compressing large amounts of water quality data into simple terms (e.g., excellent, good, poor etc.) for reporting to Environmental Managers and the public in a consistent manner (Ashwani, and Anish, 2009). WQI values revealed that if the water obtained from this water body is not treated by physical or chemical methods, it would be unsuitable for drinking. This is because the aggregated values at various stations exceeded the maximum permissible WQI for human consumption which according to Ahmad et al. (2012) was taken as 100 score. The parameters responsible for the high values of WQI as revealed by quality rating include turbidity, $\mathrm{pH}$, dissolved oxygen and biochemical oxygen demand. The concentrations of these parameters also exceeded the stipulated values by FMEnv. for surface water bechmarks.

\section{Conclusions}

The physicochemical characteristics of a stretch of Obueyinomo River were assessed in this study to determine their spatial and temporal variability and further ascertain its quality and suitability for human consumption. With the exception of turbidity, $\mathrm{pH}, \mathrm{BOD}$ and DO, the other physicochemical parameters were within Federal Ministry of Environment standard for surface water. This study further revealed that the water samples from this river should be treated before consumption by human since the estimated WQI was above 100.

\section{References}

Agu, C.C., Menkiti, M.C., Okolo, B.I. and Nnaji, P.C. (2014). Evaluation of the level and impact of selected physiochemical parameters of fertilizer effluent on Obinna River, Adani, Enugu State, Nigeria. Journal of Water Resource and Protection, 6: 722-730. 
Ahiarakwem, C.A. and Onyekuru, S.O. (2011). A Comparative Assessment of the Physico-Chemical and Microbial Trends in Njaba River, Niger Delta Basin, Southeastern Nigeria. Journal of Water Resource and Protection. 3: 686-693.

Ahmad I. K., Salih N. M. and Nzar Y. H. (2012). Determination of Water Quality Index (WQI) for Qalyasan Stream in Sulaimani City/Kurdistan Region of Iraq. Int. J. of Plant, Animal and Env. Sci. 2(4): 148-157.

Akubugwo, E.I., Ude, V.C., Uhuegbu, F.O. and Ugbogu, O. (2012). Physicochemical properties and heavy metal content of selected water sources in Ishiagu, Ebonyi State- Nigeria. Journal of Biodiversity and Environmental Sciences. 2(2): 21-27.

Anyanwu, E.D. (2012). PhysicoChemical and Some Trace Metal Analysis of Ogba River, Benin City, Nigeria. Jordan Journal of Biological Sciences. 5(1): 47 - 54.

APHA (2005). Standard Methods for the Examination of Water and Wastewater. 21 edition, Amercian Public HealthAssociation.

Washington DC.

Ashwani, K. and Anish, D. (2009). Water quality index for assessment of water quality of river Ravi at Madhopur (India).Glob. J. of Env. Sci. 8 (1): 49 - 57.

Asonye, C.C., Okolie, N.P., Okenwa, E.E. and Iwuanyanwu, U.G. (2007).

Some physico-chemical characteristics and heavy metal profiles of Nigerian rivers, streams and waterways. African Journal of Biotechnology. 6(5): 617-624.
Bhatti, M.T. and Latif, M. (2011). Assessment of water quality of a river using an indexing approach during the low-flow season. Irrigation Drainage. 60: 103-114.

Chinedu, S.N. Nwinyi, O.C. Oluwadamisi, A.Y. and Eze, V.N. (2011). Assessment of water quality in Canaanland, Ota, Southwest Nigeria. Agriculture and Biology Journal of North America. 2 (4): 577-583.

Cude, C. (2001). Oregon water quality index: A tool for evaluating water quality management effectiveness. J. Amer. Water Res. Ass. 37: 125137.

Department of Water Affairs and Forestry - DWAF (1993).Water Quality Gudeline.The Government printers Press. volume 4.

Dimowo, B.O. (2013). Assessment of Some Physico-chemical parameters of river Ogun (Abeokuta, Ogun State, Southwestern Nigeria) in Comparison with national and international standards.

International Journal of Aquaculture, 3(15): 79-84.

Duru, M. and Nwanekwu, K. (2012) Physicochemical and microbial status of Nworie River, Owerri, Imo State, Nigeria. Asian J. Plant Sci. Res., 2 (4):433-436.

Egboh, S.H.O. and Emeshili, E.M. (2007). Physicochemical characteristics of River Ethiope source in Umuaja, Delta State, Nigeria. J. Chem. Soc. Nigeria. 32(2):72-76.

Ekhaise, F.O. and Anyasi, C.C. (2005). Influence of breweries effluent discharge on the microbiological and physicochemical quality of 
Ikpoba River, Nigeria. African Journal of Biotechnology. 4 (10): 1062-1065.

Ekhator, O., Akoma, O.C. and OgieOdia, E. (2012) A Comparative limnological and water quality assessment of some rivers in Benin City And Peri-Urban areas,Edo State, Nigeria. Global Research Journal of Microbiology. 2(1): 090095.

Lawson, E.O. (2011). Physico-Chemical Parameters and Heavy Metal Contents of Water from the Mangrove Swamps of Lagos Lagoon, Lagos, Nigeria, Advances in Biological Research. 5(1): 8-21.

Monteiro, M.I.C., Ferreira, F.N., de Oliveira, N.M.M. and Ávila, A.K. (2003). Simplified Version of Sodium Salicylate Method for Analysis of Nitrate in Drinking Waters, Analytica Chimica Acta. 477: 125-129.

Murhekar, G. H. (2011). Determination of Physico-Chemical Parameters of Surface Water Samples in and around Akot City, International Journal of Research in Chemistry and Environment. 1(2): 183-187.

Nduka, J.K., Orisakwe, O.E. and Ezenweke, L.O. (2008), Some Physicochemical Parameters of Potable Water Supply in Warri, Niger Delta Area of Nigeria, Scientific Research and Essay, 3(11): 547-551.

Odoemelam, S.A., Okorie, D.O. and Oko, I.O. (2013). Physicochemical parameters and heavy metal content of water, fish and sediments from cross river at Afikpo North local Government area of Ebonyi state,
Nigeria. Bioresearch Bulletin. 010015.

Ogbeibu, A.E. Anagboso, M.U. (2003). Baseline limnological investigation of the Utor River in Esan southeast, Edo state, southern Nigeria: Physical and chemical hydrology. Tropical Freshwater Biology. 12/13: 45-62.

Ojekunle, I.A. (2000). Transport and Urban Environmental Quality in Nigeria in Contemporary to $A D$ 2000, Frankad Publishers, Lagos.

Olorode, O.A., Bamigbola, E.A., and Ogba, O.M. (2015). Comparative Studies of some River Waters in Port Harcourt based on Their Physico-Chemical and Microbiological analysis, Niger Delta Region of Nigeria. International Journal of Basic and Applied Science. 3(3): 29-37.

Omaka, O.N. (2007). Phosphorus in the Environment, Effects of Eutrophication, Cycle, Fractionation, Determination and Procedures for Sampling and Storage - A Review. Journal of Applied and Natural Sciences, 1(1): 27-36.

Prior, H. and Johnes, P.J. (2002). Regulation of surface water quality in a Cretaceous chalk catchment, UK: an Assessment of the relative importance of instream and wetland processes. The Science of the Total Environment. 283: 159-174.

Rim-Rukeh, A., Ikhifa, O.G. and Okokoyo, A.P. (2006). Effects of Agricultural Activities on the Water Quality of Orogodo River, Agbor Nigeria. Journal of Applied Sciences Research, 2(5): 256-259. 
Taiwo, A.G., Adewunmi, A.R., Ajayi, J.O., Oseni, O.A. and Lanre-Iyanda, Y.A. (2014). Physico-Chemical and Microbial Analysis of the Impact of Abatoir Effluents on Ogun River Course. International Journal of Chem Tech Research. 6(5): 30833090.

Ugwu, A.I. and Wakawa, R.J. (2012). A study of seasonal physicochemical parameters in River Usma. American Journal of Environmental Science. 8(5): 569-576.

US Environmental Protection Agency (1976). Quality criteria for water:Office of Water and Hazardous Materials Rep. EPA440/9-76-023, Washington, DC.
WHO (2011). Guidelines for DrinkingWater Quality, 4th ed. World Health Organisation, Geneva, Switzerland.

Zanin, L., Robertson, W.D., Ptacek, C.J. and Schiff, S.L. (1998). Phosphorus characterization in sediments impacted by septic effluent at four sites in Central Canada, Journal of Contaminant Hydrology, 33: 405429.

Zatar, N.A., Abu-Eid, M.A. and Eid, A.F. (1999). Spectrophotometric Determination of Nitrite and Nitrate Using Phosphomolybdenum Blue Complex, Talanta, 50: 819-826. 